\title{
Sleep Board Review Question: Restless Legs
}

Olabimpe Omobomi, MD MPH

Rohit Budhiraja, MD

Division of Sleep Medicine

Brigham and Women's Hospital

Harvard Medical School

Boston, MA USA

Ms. Jones (not her real name) is a 63-year-old woman who states that she gets very fidgety when sitting in a theater, watching a movie or when flying long distances on a plane. She is unable to find words to describe the sensation but she states that moving her legs make them feel better. Lately, she has been getting this feeling almost every night. She reports no leg discomfort in the daytime.

She denies muscle cramps her legs. She had some recent investigations done by her primary care physician because of complaints of fatigue.

Which of the following will be helpful in the diagnosis and management in this patient?

1. An overnight polysomnogram showing apnea hypopnea index of 1.6 events per hour and no periodic limb movements (PLMs)

2. Ferritin level of $18 \mathrm{ng} / \mathrm{ml}$ (normal range $20-200 \mathrm{ng} / \mathrm{ml}$ )

3. Serum Bicarbonate of $29 \mathrm{mEq} / \mathrm{L}$ (normal range $23-29 \mathrm{mEq} / \mathrm{L}$ )

4. Thyroid Stimulating hormone (TSH) $6 \mathrm{mIU} / \mathrm{ml}$ (normal range 0.4-4.8 $\mathrm{mlU} / \mathrm{ml}$ ) 


\section{Correct! \\ 2. Ferritin level of $18 \mathrm{ng} / \mathrm{ml}$}

Ms. Jones' symptoms are highly suggestive of restless legs syndrome (RLS). Low peripheral iron stores defined as serum ferritin $<45-50 \mathrm{ng} / \mathrm{ml}$ despite being in the "normal range" has been associated with RLS. Iron deficiency is a well-defined environmental factor in RLS. Low cerebrospinal fluid (CSF) ferritin levels have also been demonstrated in RLS patients even with normal serum ferritin levels (1). Iron is an essential cofactor for tyrosine hydroxylase, which is a rate-limiting step in the conversion of levodopa to dopamine (2). Therefore, a decrease in iron may affect the availability of dopamine which is a neurotransmitter implicated in the pathophysiology of RLS. There is a circadian variation in the availability of iron and the activity of tyrosine hydroxylase, thus corresponding with the nighttime occurrence/aggravation of RLS symptoms (3). Conditions that decrease iron availability (pregnancy, end stage renal disease) demonstrate an increased prevalence of RLS.

Her TSH of $6 \mathrm{mIU} / \mathrm{ml}$ is mildly elevated and is unlikely to cause symptoms. While hypothyroidism may present with symptoms of neuropathy and myopathy, which may mimic RLS, symptoms do not demonstrate a marked circadian variation or relationship to sedentary activities (i.e. they do not typically occur only at rest and are not as noticeably alleviated by movement).

Increase in serum bicarbonate levels to the upper limits of normal or above, may be seen in hypoventilation syndromes and may be associated with daytime fatigue however this does not explain the predominantly sensory symptoms described by the patient.

RLS is a clinical diagnosis and does not require a polysomnogram for diagnosis. The revised diagnostic criteria for diagnosis of RLS set forth by the International Restless Legs Study Group (IRLSSG) in 2012 consists of four clinical criteria, and three supportive criteria (2). The presence of PLMs on polysomnography corroborates the diagnosis of RLS especially when there is doubt, but it is not an essential diagnostic criterion. Moreover, only $80 \%$ of patients with RLS have PLMs on polysomnographic monitoring.

\section{References}

1. Allen RP. Restless leg syndrome/Willis-Ekbom disease pathophysiology. Sleep Med Clin. 2015 Sep;10(3):207-14. [CrossRef] [PubMed]

2. Nagandla K, De S. Restless legs syndrome: Pathophysiology and modern management. Postgrad Med J. 2013;89(1053):402-10. [CrossRef] [PubMed]

3. Allen RP, Earley CJ. The role of iron in restless legs syndrome. Mov Disord. 2007;22 Suppl 18:S440-8. [CrossRef] [PubMed] 